\title{
昡暈症に対する鍼尒治療の効果
}

\author{
門倉 義幸 ${ }^{\mathrm{a}}$ 石田 良 ${ }^{\mathrm{a}}$ 柳 裕一郎 $\mathrm{a}$ \\ 門倉 淳二 $\mathrm{b}$ 世良田和幸 $\mathrm{c}$ 池田 尚弘 $\mathrm{d}$ \\ 洲崎 春海 $\mathrm{e}$ \\ a 昭和大学横浜市北部病院耳鼻咽喉科, 神奈川， $=224-8503$ 横浜市都筑区茅ヶ崎中央 $35-1$ \\ はる治療所，神奈川， ₹229-0026 相模原市陽光台2-3-22 \\ 昭和大学横浜市北部病院麻配科, 神奈川, =224-8503 横浜市都筑区茅ヶ崎中央 $35-1$ \\ 池田耳鼻咽喉科，東京， $=115-0055$ 北区赤羽西1-15-14 \\ 昭和大学耳鼻咽喉科学教室, 東京, $=142-8555$ 品川区旗の台1-5-8
}

\section{The Effect of Acupuncture Treatment on Patient with Vertigo}

\author{
Yoshiyuki KADOKURA $^{\mathrm{a}} \quad$ Makoto ISHIDA $^{\mathrm{a}}$ Yuichiro YANAGI ${ }^{\mathrm{a}}$ \\ Junji KADOKURA $^{\mathrm{b}} \quad$ Kazuyuki SERADA $^{\mathrm{c}} \quad$ Naohiro IKEDA $^{\mathrm{d}}$ \\ Harumi SUZAKI ${ }^{\mathrm{e}}$
}

a Department of Otolaryngology, Showa University Northern Yokohama Hospital, 35-1 Chigasakityuou, Tsuzuki-ku, Yokohama, Kanagawa 224-8503, Japan

b Haru Acupuncture Clinic, 2-3-22 Yokodai, Sagamihara, Kanagawa 229-0026, Japan

c Department of Anesthesiology, Showa University Northern Yokohama Hospital, 35-1 Chigasakityuou, Tsuzuki-ku, Yokohama, Kanagawa 224-8503, Japan

d Ikeda ENT Clinic, 1-15-14 Akabanenishi, Kita-ku, Tokyo 115-0055, Japan

e Department of Otolaryngology, Showa University, 1-5-8 Hatanodai, Shinagawa, Tokyo 142-8555, Japan

\begin{abstract}
We evaluated the clinical effects of acupuncture/moxibustion therapy in 7 patients with vertigo that was uncontrollable with western medicine. The observation period was 6-15 months. The 7 patients consisted of 1 male and 6 females aged 29-73 years (mean, 44.7 years). More than 4 courses or more of acupuncture/ moxibustion treatment (acupuncture + warm moxibustion) were performed in each patient, and the effects were evaluated based on the results of a daily living disability questionnaire before and after treatment. In practice, these effects were classified into 4 grades (cure, improvement, no change, aggravation). Cure was observed in 1 patient, improvement in 5 patients, and no change in 1 patient, indicating this therapy was effective in $85 \%$ of the patients. None of the patients showed aggravation of their condition. In addition, no adverse effects were observed.

Our results suggest that acupuncture/moxibustion therapy has certain effects on intractable vertigo. Therefore, in patients with vertigo who do not respond to western medical care, such as the administration of antivertigo drugs, a beneficial effect of acupuncture/moxibustion as a complementary therapy can be expected.

Key words : acupuncture, dermal acupuncture, warm moxibustion, vertigo, daily living disability questionnaire

\section{要旨}

西洋医学的治療で治癒困難であった未梢性眩量症患者 7 例に対し鍼负治療を行い臨床的効果を検討した。観察期

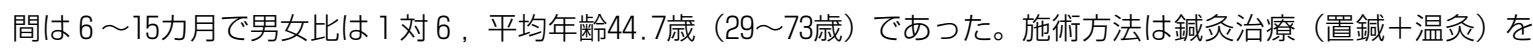
4 回以上施行, 施術前後に行った日常障害度アンケート調査結果を用いて効果判定を行った。効果は治癒・軽快· 不变. 悪化の 4 段階とした。治癒 7 例，軽快 5 例，不变 7 例であり $85 \%$ に有効性を認めた。無効例を 7 例に認めた が悪化するものは認めず，鍼炎治療による副反応は認めなかった。難治性の眩量症に対して鍼炎治療は一定の効果 を示したことから前治療として抗眩量薬等の西洋医学的治療が無効の症例では代替治療として本鍼负治療を施行す ることで治療効果が期待できる。

キーワード : 置鍼, 接触鍼, 温灭, 眩量症, 日常障害度アンケート調査
\end{abstract}


表 1 対象

\begin{tabular}{|c|c|c|c|c|c|}
\hline 症例 & 年齢·性 & 診断 & 聴力 & schellong & 前治療内容·期間 \\
\hline 1 & 29女性 & 末梢性 & 正常 & 正常 & 内服-点滴1か月 \\
\hline 2 & 29女性 & 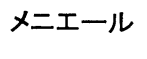 & 両低音障害 & 正常 & 内服1年6か月 \\
\hline 3 & 36女性 & 末梢性 & 正常 & 正常 & 内服·点滴9ヶ月 \\
\hline 4 & 35女性 & $x$ ニエール & 左低音障害 & 正常 & 内服·点滴1年4か月 \\
\hline 5 & 73男性 & 末梢性 & 正常 & 正常 & 内服6か月 \\
\hline 6 & 52女性 & 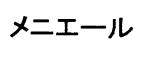 & 右水平型難聴 & 未検査 & 内服1か月 \\
\hline 7 & 59女性 & 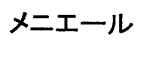 & 右低音障害 & 正常 & 内服·点滴1か月 \\
\hline
\end{tabular}

\section{緒言}

近年，海外を中心に多種の疾患・症状に対する鍼 尒治療の有効性が報告されている ${ }^{1) \sim 4}$ 。

今回, 耳鼻咽喉科的治療で効果を認めなかった末 梢性眩暈症患者に対して銊尒治療を施し，その効果 を臨床的に検討し若干の知見を得たので報告する。

我々耳鼻咽喉科医は，日常診療において眩暈を主 訴に来院する患者の診察にあたる機会は多い。しか しながら，多忙な外来診療においては原因疾患の特 定されない末梢性矓量患者に対し抗矓量薬の投薬と 簡便な生活指導のみで対応しているのが現状である。 眩量は一般に軽症ととらえられがちであるが，患者 は軽快・増悪を繰り返す矓量に悩み, 日常生活に支 障をきたしている場合が少なくない。したがって， その治療に対して，西洋医学的アプローチで効果を 認めない場合は, より効果的な治療法の検討が必要 である。

今回我々は，末梢性眩暈症と診断されたが，西洋 医学的アプローチ(投薬・生活指導)にてコントロー ル不可能であった患者 7 例に対し銊炎治療を施行し， その効果を臨床的に検討した。

\section{対象および方法}

\section{1. 対象}

2001年 5 月～2003年 12 月の期間に，昭和大学横浜 市北部病院耳鼻咽喉科外来及び当科連携病院で末梢 性眩暈症と診断され西洋医学的治療を受けたが，治 療効果を認めなかった患者 7 名（男：女＝1：6， 年齢29～73歳，平均年齢44.7歳）を対象とした。

表 1 に 7 例の詳細を示す。 7 例中 2 例は既に他院
耳鼻咽喉科医師による確定診断の後，初回治療がな され，5例は当院及び当院連携病院にて初回治療を 行った。西洋医学的治療を当院で施行した期間は 1 〜18力月（平均 9 力月）であった。心理テスト（日 本語版 STA I test )を 4 名に，その他 3 例に対して詳 細な問診を行うことで心因性めまいを否定した。ま た全例に頭部 MRI が撮影され中枢性めまいを否定 した。

2. 方法

鍼炎治療を 4 回以上施行し施術の前後で日常障害 度アンケートを行った。アンケートは大阪大式（表 2 $)^{5)}$ を使用し, その合計点数の変化（14～70点：点 数が高いほど高度障害）で評価した。評価方法は， アンケート合計点数が治療の結果14点のものを治癒, 合計点数が減少したものを軽快，合計点数に変化の なかったものを不変, 合計点数の増加したものを悪 化とした。また，軽快以上を有効例とし有効率を算 出した。なお，全症例について施術後少なくとも 6 カ月以上観察し，その間に眩軍に随伴した他の症状

（肩こり・腰痛 ·生理痛など）に関しても症状の変 化を調査した。

患者の多くは，胃不快感・便秘・食欲低下などの 消化器症状，腰背部痛などの腎 ·脾経の症状 - 所見 を有しており，下記の経穴を取穴治療し効果を検討 するプロトコールとした。

(腎経) 湧泉 然谷 太奚谷 大鍾 水泉 照海 復 溜 交信 築賓 陰谷

(脾経) 大都 太白 公孫 三陰交 漏谷 地機 陰陵泉 
表 2 日常生活の障害度に関するアンケート（大阪大式）

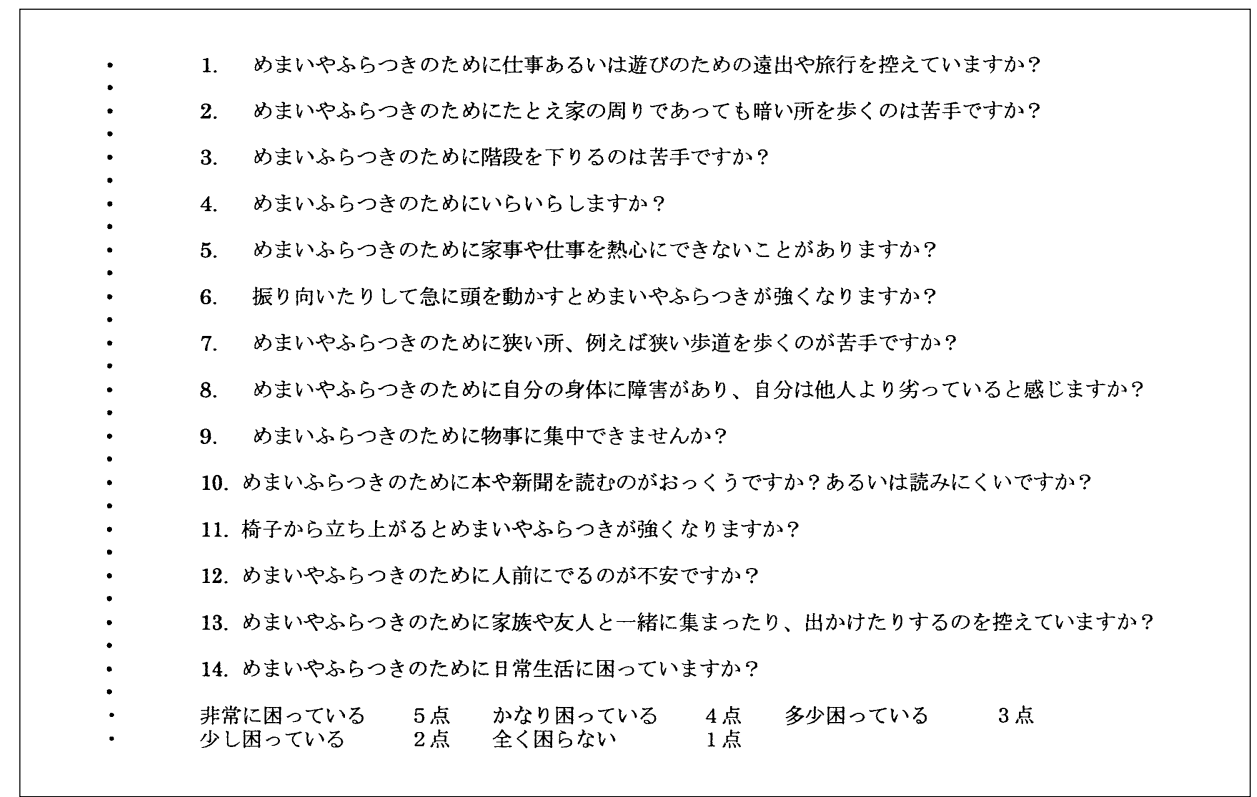

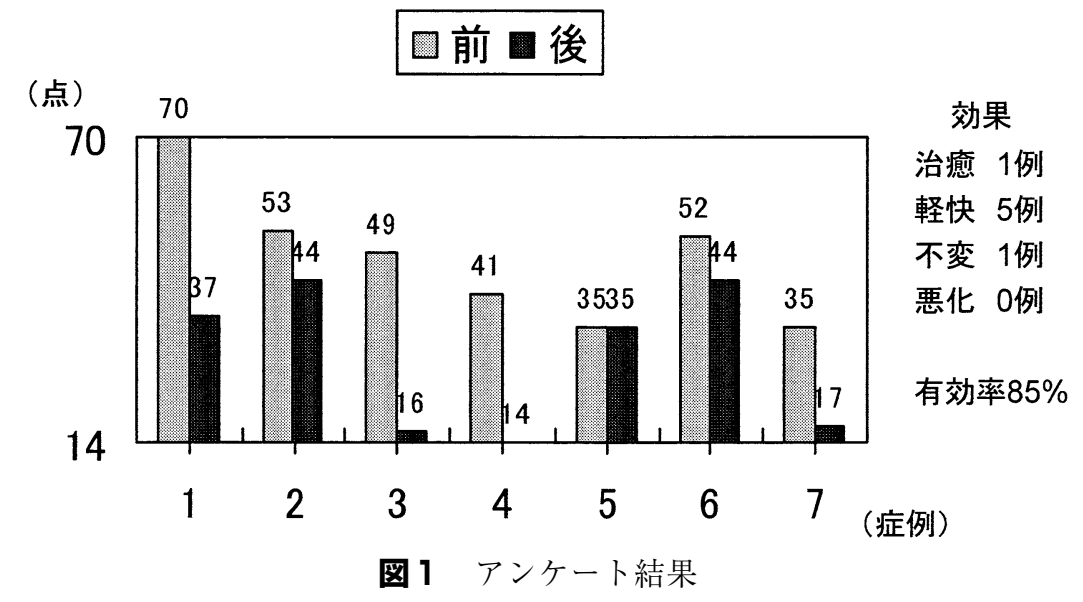

(心経) 少海

(小腸経) 後谿

(膀胱経) 承山 飛陽 跗陽

(心包経) 曲沢 郄門 内関

(肝経) 膝関 曲泉

これら経穴の硬結・浮腫・陷凹・冷えの有無を確 認したうえで取穴，所見のある経穴にのみ治療した。 特に陰経である腎経の取穴を重要視した。施術銊は セイリン株式会社製ディスポーザブル鍼，長さ40 $\mathrm{mm}$ ，長径 $0.16 \mathrm{~mm}$ を用いた。手技は接触鍼，置鍼 を行い，部位によっては棒尒を使用した温炎を行う 方法とした。具体的には, 緊張している経穴には鍼 を 3〜 $4 \mathrm{~mm}$ 直刺し緊張を緩め，1〜15分置鍼した。 陥凹している経穴・冷えている経穴には全例に温炎
を行った。

\section{結果}

観察期間は 6〜15力月（平均観察期間は 9 力月), 鍼炎治療回数は $7 \sim 60$ 回（平均24回）であった。

治療前後におけるアンケート結果の推移は図 1 の 如くで，施術前35点～70点（平均47.9点）であった が，施術後14点～44点（平均29.6点）となり，各症 例についての効果としては, 治癒 1 例 $(41 \rightarrow 14$ 点 $)$, 軽快 5 例 $(70 \rightarrow 37$ 点 $\cdot 53 \rightarrow 44$ 点 $\cdot 35 \rightarrow 17$ 点 $\cdot 49 \rightarrow 16$ 点・ $52 \rightarrow 44$ 点), 不変 1 例 $(35 \rightarrow 35$ 点 $)$, 悪化 0 例で あり，有効率は $85 \%$ であった。

眩軍以外の随伴症状で今回の治療により効果を認 めた症状としては，胃症状 4 例，耳閉塞感 3 例，頭 痛 2 例, 肩凝り 2 例, 腰背部痛 2 例, 便秘 2 例, 不 
眠 2 例, 生理不順 2 例, 下肢の異常感 2 例, 滕痛 1 例，前腕痛 1 例，夜間頻尿 1 例，眼球乾燥 1 例であ り，その他，不妊治療中に妊娠に成功した症例が 1 例あった。(表 3 )

\section{考察}

今回の検討は，眩軍症状を伴う女性患者の頑固な 肩凝り・腰痛に対して, 著者が筋緊張状態を緩和す ベく依頼した鍼炎治療後に肩凝り・腰痛だけでなく 眩軍症状まで著明に軽快した症例を経験したことに 端を発す。

近年，海外より銊炎治療によるさまざまな疾患・ 症状に対する有効性が報告され，特に術後歯痛・背 部痛・肩の疼痛・分婏中胎位異常などへの治療に関

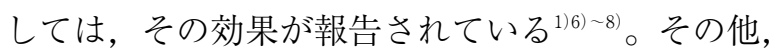
注目されている鍼多治療対象症状・疾患としては, 各種疾患における疼痛コントロール（特に癌性疼痛 - 腰痛・膝痛 · 月経痛), 手根管症候群, テニス肘,

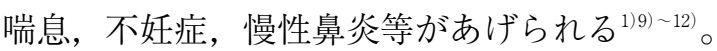

こうしたことから国内でも多数の病医院にて銊尒 治療を導入する施設が散見される。

当院でも2001年 5 月より医師による銊尒治療を開 始し, さまざまな耳鼻咽喉科疾患に対し，その効果 を検討中である。しかしながら，鍼炎治療の効果を 科学的に検討する際の, コントロール群の設定や症 例数の確保などが困難で，一般的疾患・症状への治 療効果のランダム化比較試験の実施も困難な場合が 多く，また，鍼多治療の作用機序についても不明な 点が多い。

我々耳鼻咽喉科医は, 眩暈を訴える患者に対して 常にその原因を精査するように努めてはいるが，原 因が不明で診断のつかない患者を臨床上, 時に経験 することも稀ではない。嘉村らは，めまい外来に来 院した患者10712例の統計的検討において, 診断の ついた症例は6781例（63.3\%）であり, 原因の確定 できない症例が3931人 $(36.7 \%)$ 存在した ${ }^{13)}$ として おり，こうした西洋医学的に分類不能の眩暈患者に 対しての対応は困難な状況にある。

短期間に軽快し反復のない末梢性眩量患者に対す る治療は, 従来通りの抗眩軍薬や生活指導で充分対 応できる。今回検討した眩暈患者は全例その範疇に なく, 施術前のアンケート調査で，生活活動範囲を 制限していることや家事が思うようにできないこと など全例で QOL の低下が確認された症例である。
表 3 随伴症状

\begin{tabular}{|l|l|}
\hline 症例 & \multicolumn{1}{|c|}{ 随伴症状 } \\
\hline 1 & 胃不快·耳閉感·生理痛·肩凝り \\
\hline 2 & 生理痛 \\
\hline 3 & 胃不快·生理痛·背部痛·前腕痛 \\
\hline 4 & 胃不快·耳閉感·頭痛·腰背部痛 \\
\hline 5 & 夜間頻尿 \\
\hline 6 & 不眠·便秘·下肢痛 \\
\hline 7 & $\begin{array}{l}\text { 胃不快·耳閉感·頭痛·肩凝り·不眠·便秘· } \\
\text { 膝痛·下肢痛·眼球乾燥 }\end{array}$ \\
\hline
\end{tabular}

今回，ランダム化比較試験に比較すると客観性に そしい検討方法ではあるが，難治性の眩量症に対し 本治療法の一定の有効性が確認された。西洋医学的 アプローチ（投薬・生活指導）を行っても眩暈を反 復する症例に対し，代替医療として銊多治療を行う 価値は十分あるものと考えられた。その作用機序は 不明であるが, 我々は 1 . 随伴症状の消失・改善が 各患者 $\mathrm{ADL}$ を改善させ，身体平衡の維持にとって 重要な前庭器, 視器, 深部知覚器への入力情報が増 加し, 平衡機能回復に寄与した, 2 . 末梢循環改善 作用が期待されることから内耳の微小循環を改善さ せ抗眩軍作用に関与した，の 2 つ可能性を考えて いる。

施術にあたっての問題点は，i）一回の治療時間 を最低30分程度要する，ii）医療保険請求できない, iii）施術方法が鍼尒師ごとに異なるため統一した治 療方法が立証されていない，iv）一度で効果を認め ないことが多いため複数回施行する必要がある，な どがあげられる。

一方利点は，i） Ernst らの報告の如く適切な部 位への銊治療が行われた場合に安全で, 副反応が少 ない ${ }^{14)}$, ii ）同じ東洋医学的治療である漢方薬治療 に比較し即効性が期待できる, iii）眩軍以外の随伴 症状が改善される，などがあげられる。

今回は, 全症例で大学病院において平衡機能検査 ・MRI ・ 純音聴力検査などが施行されており問題は ないと考えるが，一般鍼尒院での治療にあたっては， 時に注意すべき眩軍患者が存在することを念頭に置 く必要がある。具体的には, 脳腫瘍, 小脳出血, 小 脳梗塞, 椎骨脳底動脈解離などの中枢性眩軍症と蝸 牛症状（聴力低下，耳鳴り）が随伴する眩暈である 突発性難聴，メニエール病，外リンパ瘦などである。 これらの疾患に対しては, 西洋医学的治療が発症早 
期から必要となる。また，ステロイド療法を中心と した西洋医学的治療が必須である突発性難聴やメ二 エール病初回発作などでは, 患者が螖牛症状を自覚 せずに来院し見落とす可能性があるため, 問診は慎 重に行う必要がある。さらに，一見心因性の眩軍症 と思われるような症例でも, 眩暈患者は発作が反復 する場合には，心因面でうつ傾向を示すことがあり， 安易に心因性眩暈症と診断してはならない。

今回は症例数が少なく，眩軍症に対する鍼炎治療 効果の有効性検討には十分ではなかったかもしれな い。今後，重心動摇検査・眼振所見の変化・消失な ど客観的評価を加え追試する必要があると考えてい る。

大学病院をはじめ，日本の医療施設における鍼尒 治療への関心は今後も益々加速していくものと思わ れる。我々医師も鍼炎治療に対して知識を深め, 適 応と思われる疾患に対しては積極的に施術すること を検討したい。しかしながら，実際の臨床上，時間 的制約が多く施行困難と考えられる場合には，近隣 の鍼尒院や鍼多師と密に連携し，治療していくこと が重要である。

\section{結語}

1. 西洋医学的治療で治癒困難であった末梢性眩 軍症患者 7 例に対し，鍼炎治療を行い，日常障害度 アンケートを用いて臨床効果を検討した。

2 . 鍼尒治療の結果, 治癒 1 例, 軽快 5 例であ り，85\%に有効性を認めた。1例については，不変 であったが，悪化するものはなかった。

3．鍼炎治療による副反応は認めなかった。

4. 鍼炎治療による眩暈随伴症状消失・改善作用 と内耳微小循環改善作用が平衡機能回復に関与する 可能性がある。

附記 : 本論文の要旨は第55回日本東洋医学会学術総 会（2004年，横浜）で報告した。

\section{参考文献}

1 ) NIH. Consensus conference, Acupuncutre. JAMA, $280: 1518-1524$ (1998)

2) Heikkila H, Johansson M, Wenngren B.-I : Effects of acupuncture, cervical manipulation and NSAID therapy on dizziness and impaired head repositioning of suspected cervical origin : a pilot study. Manual Therapy, 5(3), 151-157 (2000)

3 ) Lin J.-G, Lo M.-W, Wen Y.-R, Hsieh C.-L, Tsai S.-K, Sun W.-Z: The effect of high and low frequency electroacupuncture in pain after lower abdominal surgery. Pain 99, 509-514 (2002)

4 ) Schiff E, Oliven A, Odeh M: Acupuncture therapy for sleep related laryngospasm. Am J Med Sci, 326 (2), 107-109 (2003)

5 ）北原 糺, 武田憲昭, 肥塚 泉, 西池季隆, 荻野 仁，久保 武：めまいに対するブロマゼパムの 治療効果, Equilibrium Res, 57(4)，401-407(1998)

6) Patel M, Gutzwiller F, Marazzi A : A meta-analysis of acupuncture for chronic pain. Int J Epidemiol 18 (4) , 900-906 (1989)

7 ) Juan G, Elena B, Maria A, Francisco V, Maria G : Acupuncture for soft tissue shoulder disorders: A series of 201cases. Acupuncture in Medicine, 21(12), 18-22 (2003)

8 ) Cardini F., Weixin H. : Moxibustion for correction of breech presentation a randomized controlled trial. JAMA， 280，1580-1584（1998）

9 ) Molsberger A, Hille E. : The analgesic effect of acupuncture in chronic tennis elbow pain. Rheumatology, 33, 1162-1165 (1994)

10) Paulus WE., Zhang M., Strehler E., El-Danasouri I., Sterzik K. : Influence of acupuncture on the pregnancy rate in patients who undergo assisted reproduction therapy. Fertil Steril， 77 (4)， 721-724（2002）

11) Xue CC, English R, Zhang JJ, Costa CD, Li CG : Effect of acupuncture in the treatment of seasonal allergic rhinitis : a randomized clinical trial. Am.J.Chin. Med. 30(1) , 1 -11 (2002)

12) Petti FB, Liguori A, Ippoliti F : Study on cytokines IL - 2, IL- 6 , IL-10 in patients of chronic allergic rhinitis treated with acupuncture. J.Tradit.Chin.Med. 22 (2), 104-111 (2002)

13）嘉村恵理子, 相原康孝, 山口 潤, 八木聰明：め まい外来 1 万例の統計的検討, 耳喉頭頸, 71(13), 901-906 (1999)

14) Ernst G, Strzyz H, Hagmeister H. : Incidence of adverse effects during acupuncture therapy -a multicentre survey. Complement Ther Med，11，93-97(2003) 